\title{
Herbivory and the resilience of Caribbean coral reefs: knowledge gaps and implications for management
}

\author{
Thomas C. Adam ${ }^{1,4, *}$, Deron E. Burkepile ${ }^{1}$, Benjamin I. Ruttenberg ${ }^{2}$, \\ Michelle J. Paddack ${ }^{3}$ \\ ${ }^{1}$ Marine Sciences Program, Department of Biological Sciences, Florida International University, North Miami, FL 33181, USA \\ ${ }^{2}$ NOAA Fisheries, Southeast Fisheries Science Center, Miami, FL 33149, USA and Biological Sciences Department, California \\ Polytechnic State University, San Luis Obispo, CA 93410, USA \\ ${ }^{3}$ Biological Sciences Department, Santa Barbara City College, Santa Barbara, CA 93109, USA \\ ${ }^{4}$ Present address: Marine Science Institute, University of California, Santa Barbara, CA 93106, USA
}

ABSTRACT: Herbivory is a key process on coral reefs that can facilitate reef-building corals by excluding algae that otherwise negatively impact coral settlement, growth, and survivorship. Over the last several decades, coral cover on Caribbean reefs has declined precipitously. On many reefs, large structurally complex corals have been replaced by algae and other non-reef-building organisms, resulting in the collapse of physical structure and the loss of critical ecosystem services. The drivers of coral decline on Caribbean reefs are complex and vary among locations. On many reefs, populations of key herbivores have been greatly reduced by disease and overfishing, and this has resulted in the proliferation of algae that hinder coral recovery following major disturbances. Yet, evidence that increases in herbivory can promote coral recovery on Caribbean reefs has been mixed. Here, we discuss key contingencies that will modify the relationships between herbivores, algae, and corals and identify critical knowledge gaps that limit our ability to predict when and where herbivores are most likely to facilitate coral persistence and recovery. Impacts of herbivores on coral reef ecosystems will vary greatly in space and time and will depend on herbivore diversity and species identity. While there are still a large number of knowledge gaps, we make several management recommendations based on our current understanding of the processes that structure reef ecosystems. Reversing the fate of Caribbean coral reefs will require the development of integrated management strategies that simultaneously address multiple stressors in addition to the impacts of fisheries on herbivore assemblages.

KEY WORDS: Phase shift · Grazing impacts · Macroalgae · Parrotfish $\cdot$ Fishing $\cdot$ Diadema $\cdot$ Climate change $\cdot$ Restoration

Resale or republication not permitted without written consent of the publisher

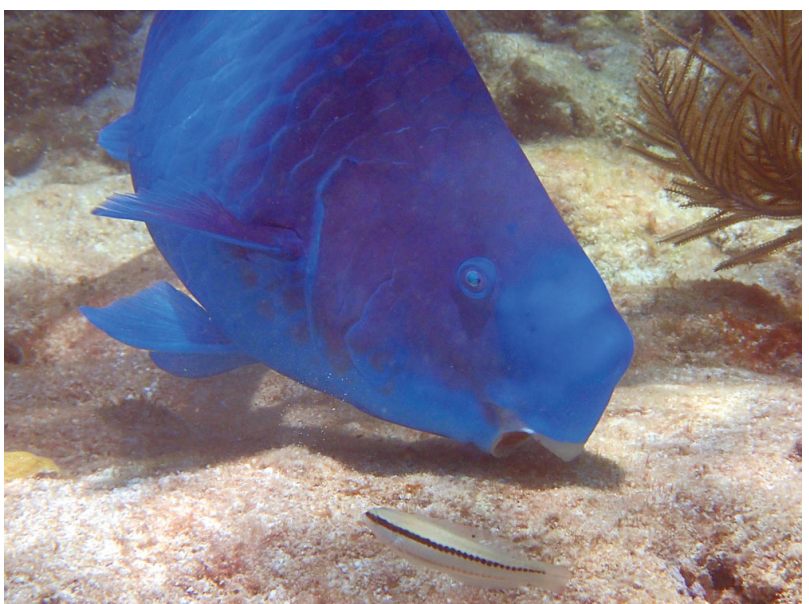

Blue parrotfish Scarus coeruleus cropping algae on a reef.

Photo: T. C. Adam

\section{INTRODUCTION}

Coral reefs support fisheries that are essential for the well-being of millions of people (Pauly et al. 2002). However, these fisheries often target species which perform important ecological functions, such as herbivorous fishes, whose grazing prevents the proliferation of algae that compete with corals for space (Koslow et al. 1988, Bellwood et al. 2004, McClanahan \& Cinner 2008). Because removal of herbivores can shift the competitive balance between algae and reef-building corals, fishing could reduce the capacity of corals to withstand or recover from perturbations, including those resulting from 
coastal development and global climate change (Bellwood et al. 2004, Mumby 2006, Hughes et al. 2010). Thus, there are likely to be important trade-offs between short-term fisheries goals of maximizing yield and profit and the long-term sustainability of coral reef ecosystems and the services they provide (Brown \& Mumby 2014).

In light of these trade-offs, it is critical to understand how fishing impacts reef-building corals by altering the process of herbivory on coral reefs. Intense feeding by herbivorous fishes and sea urchins favors corals by excluding upright macroalgae and facilitating the development of benthic communities dominated by taxa tolerant to grazing, including crustose coralline algae and closely cropped filamentous turfs (Steneck 1988, Hay 1991, Carpenter 1997), which tend to have neutral or positive impacts on corals (Harrington et al. 2004, Price 2010, Barott et al. 2012). In contrast, the macroalgae and dense turfs that develop under low grazing regimes negatively impact settlement of coral larvae as well as growth and survivorship of adult corals (River \& Edmunds 2001, Nugues \& Szmant 2006, Box \& Mumby 2007, Rasher \& Hay 2010, Vega Thurber et al. 2012).

However, these broad generalizations about herbivore-algae-coral interactions are likely contextdependent. For example, herbivores differ greatly in their feeding preferences and behaviors, and consequently different species have unique impacts on benthic communities (Choat et al. 2004, Mantyka \& Bellwood 2007, Burkepile \& Hay 2008). Herbivores also vary widely in their susceptibility to fishing and other anthropogenic stressors (Bellwood et al. 2012, Edwards et al. 2014). In addition, other factors besides competition with algae can limit coral success, such as sedimentation, nutrient loading, and disease (McClanahan et al. 2002). Therefore, it is critical to understand the roles that particular types of herbivores play in limiting harmful algae and facilitating corals under a range of environmental conditions to improve sustainable management of coral reef ecosystems.

In this manuscript, we identify critical knowledge gaps which limit our ability to predict when herbivores are likely to promote coral persistence and recovery. We also explore what types of management interventions may be most effective for maintaining healthy coral reef ecosystems. In particular, we ask questions centered around 3 main topics: (1) What processes operate to prevent or facilitate coral persistence and recovery, and how are these influenced by herbivory? (2) What are the independent and combined effects of different species of herbivores in limiting algae and facilitating reef-building corals?
(3) What factors limit herbivore populations and the process of herbivory on coral reefs? We focus on coral reefs throughout the wider Caribbean basin, where fishing pressure is high, coral decline has been severe, and algae have increased in abundance in recent decades (Gardner et al. 2003, Bruno et al. 2009, Schutte et al. 2010, Jackson et al. 2014).

Coral cover began declining throughout much of the Caribbean in the early 1980s following several major hurricanes, a coral disease epidemic, and the proliferation of macroalgae following the mass dieoff of the herbivorous sea urchin Diadema antillarum (Gardner et al. 2003, Schutte et al. 2010, Jackson et al. 2014). In subsequent years, corals have continued to decline in response to a complex combination of chronic and acute drivers, including declining water quality (Rogers 1990, Fabricius 2005, Sutherland et al. 2011), increases in the frequency and severity of mass bleaching events (Baker et al. 2008, Eakin et al. 2010), and impacts from several of the most active hurricane seasons on record (Gardner et al. 2005, Williams \& Miller 2012). During this time, large reefbuilding corals have experienced especially steep declines, resulting in a rapid collapse in structural complexity (Alvarez-Filip et al. 2011) and cascading indirect effects on reef-associated biota including reef fishes (Paddack et al. 2009). Declines in coral cover have been accompanied by abrupt shifts in community structure, with once-dominant corals being replaced by smaller weedy coral species, nonreef-building invertebrates, and/or fleshy macroalgae (Green et al. 2008, Norström et al. 2009, Schutte et al. 2010, Burman et al. 2012, Ruzicka et al. 2013, Toth et al. 2014). These persistent changes are unprecedented in the recent geologic past (Jackson 1992, Aronson \& Precht 1997, Pandolfi \& Jackson 2006), giving rise to the paradigm that human activity has caused a regime shift throughout the Caribbean (Knowlton 1992, Mumby \& Steneck 2008, Hughes et al. 2010).

A central tenet of this paradigm is that the reefs of the 1980s were unexpectedly vulnerable to disturbance due to the serial depletion of important consumers-especially herbivorous fishes -in the decades prior to ecosystem collapse (Jackson 1997, Jackson et al. 2001, Pandolfi et al. 2003). As a consequence, the die-off of $D$. antillarum triggered a rapid 'phase shift' to algal dominance by removing the last remaining abundant herbivore in many places in the Caribbean (e.g. Hughes 1994). In addition to being a symptom of the larger regime shift, algae are widely believed to play a critical role in preventing coral recovery, prompting strong calls for the protection of 
herbivorous fishes (Bellwood et al. 2004, Mumby \& Steneck 2008, Hughes et al. 2010, Jackson et al. 2014). However, evidence that herbivorous fishes can promote coral recovery on Caribbean reefs has been inconsistent. Whereas localized recovery of $D$. antillarum has been strongly associated with heightened coral recruitment and enhanced growth and survivorship of juvenile corals (Edmunds \& Carpenter 2001, Carpenter \& Edmunds 2006, Myhre \& AcevedoGutiérrez 2007, Furman \& Heck 2009, Idjadi et al. 2010), studies throughout the Caribbean have often failed to find strong links between the biomass of herbivorous fishes and coral cover (e.g. Newman et al. 2006, Sandin et al. 2008, Burkepile et al. 2013). Further, a recent meta-analysis suggests that protection of herbivorous fishes within marine protected areas has not been associated with increases in coral cover relative to fished locations (Guarderas et al. 2011; but see Mumby \& Harborne 2010, Selig \& Bruno 2010).

The emerging picture suggests that impacts of herbivores on coral recovery are likely to be highly context-dependent. A deeper understanding of the relationships between different types of herbivores, algae, and corals is therefore needed to facilitate management. With this goal in mind, we identify critical knowledge gaps regarding the ability of herbivores to promote coral recovery under a range of environmental conditions. These gaps are presented as a series of broad research questions, which, if addressed, would improve the capacity of managers to prioritize strategies for recovering and/or maintaining healthy coral reef ecosystems.

\section{KNOWLEDGE GAPS}

\section{Question 1. What processes operate to prevent or facilitate coral persistence and recovery and how are these influenced by herbivory?}

Understanding the factors that confer resilience to coral reefs is critical for understanding the recent trajectory of Caribbean reefs and for predicting their future dynamics. Here, we define resilience as the capacity of a reef to recover (i.e. return to its previous state) following an acute perturbation such as a hurricane or coral bleaching event. Healthy herbivore populations may be an important factor leading to resilience by preventing the establishment and proliferation of algae following disturbances. While many Caribbean reefs have failed to recover from recent disturbances (but see Manfrino et al. 2013), reefs in the Indo-Pacific often recover rapidly from acute pulse disturbances (Connell 1997, Sheppard et al. 2008, Adjeroud et al. 2009, Gilmour et al. 2013), indicating a high level of resilience that is often linked to robust herbivore populations.

However, the extent that herbivores can promote resilience will depend on the range of factors limiting both coral and algal populations and impacting the ability of herbivory to mediate interactions between the two. Reef ecosystems are heterogeneous seascapes consisting of a mosaic of individual reefs, each with different physical and biological characteristics and at different successional stages. Consequently, the factors limiting coral, algae, and herbivore populations will vary greatly in space. Acute pulse perturbations such as hurricanes and bleaching events, as well as chronic press-perturbations such as pollution and sedimentation, can further modify herbivorealgae-coral interactions. Impacts of herbivores can also depend on the presence of feedbacks that can reduce herbivory, facilitate algae, and impede coral recovery following a perturbation (Knowlton 1992, Mumby \& Steneck 2008, Nyström et al. 2012). The ability of herbivores to facilitate the maintenance and recovery of resilient coral reefs will therefore be highly context-dependent (McClanahan et al. 2002, Aronson \& Precht 2006). Understanding how ex

ternal drivers such as hurricanes, coral bleaching events, and local anthropogenic impacts can interact with feedbacks to reduce herbivory and prevent coral recovery requires careful consideration of the wide range of scales over which these processes operate. Even large perturbations initially operate on local scales to disrupt ecological interactions on individual reefs. However, as perturbations become more frequent and/or spatially extensive, they will begin to alter patterns of connectivity among reefs in the wider seascape (Fig. 1). In this section we ask how the impacts of herbivores on coral persistence and recovery will vary in space and time due to variation in human impacts and the natural factors that shape benthic communities on coral reefs.

How do ecological feedbacks mediate the impacts of herbivores on reef dynamics?

Understanding the factors responsible for recent coral decline on Caribbean reefs is critical for the development of effective management strategies because corals are unlikely to recover if the chronic causes of coral mortality are not addressed. However, on many reefs, factors in addition to those respon- 


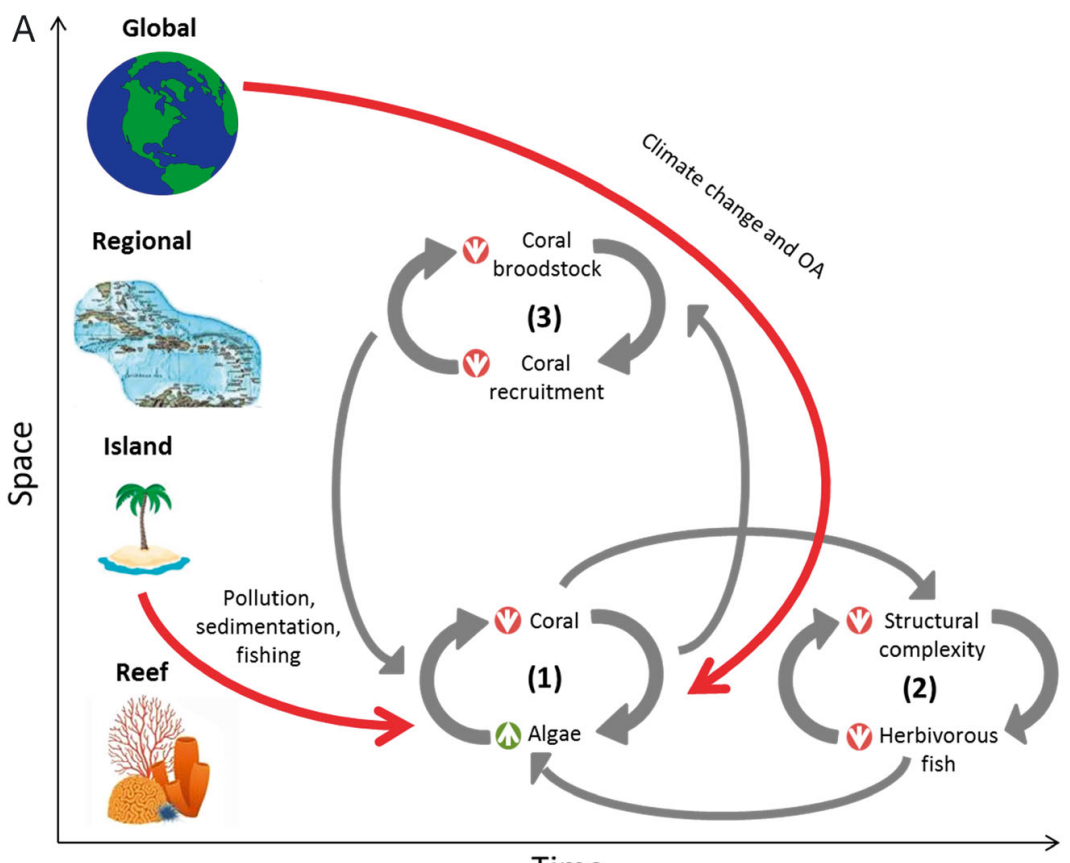

Time

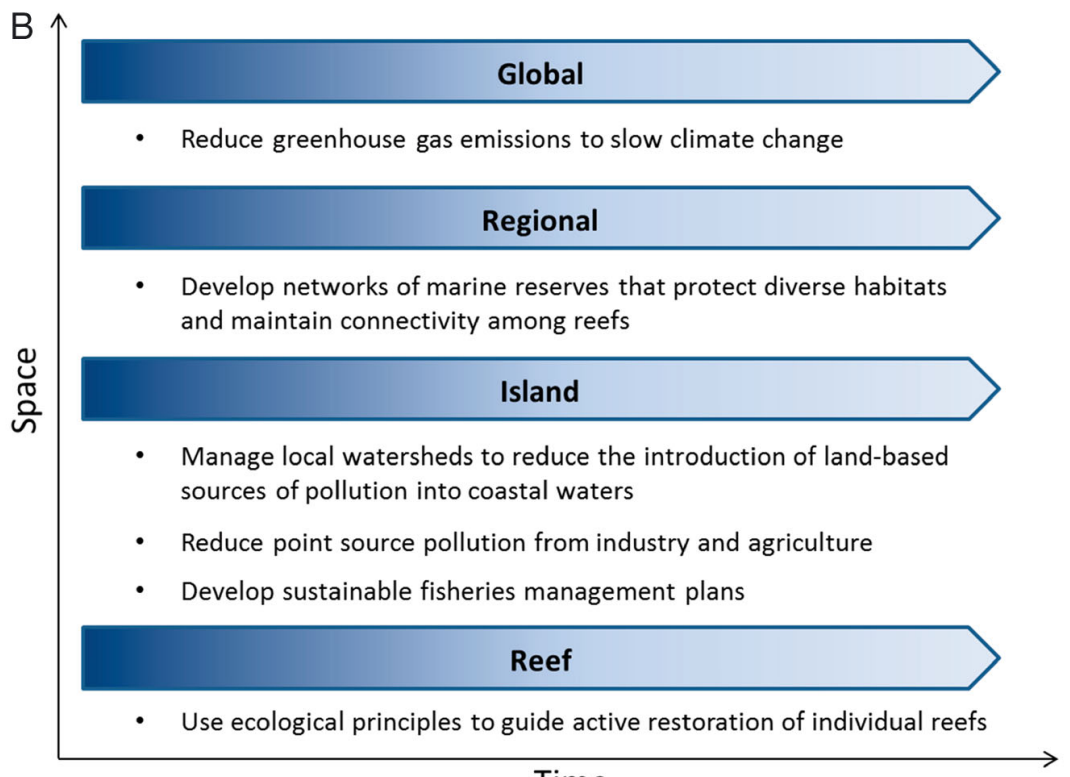

Time

Fig. 1. (A) Illustration of the external drivers (red arrows) and internal feedbacks (gray arrows) that can lead to coral decline and prevent coral recovery on degraded reefs (modified from Nyström et al. 2012). Feedbacks generated by local competitive interactions between corals and algae are influenced by local factors such as nutrient loading, sedimentation, and overfishing, as well as global increases in $\mathrm{CO}_{2}$ emissions which can interact to directly kill corals and slow coral growth relative to algae (1). Feedbacks are strengthened through time as 3-dimensionally complex coral reefs degrade, reducing habitat for herbivorous fishes and further reinforcing an algae-dominated state (2). As the number of degraded reefs increases, fewer corals remain for effective reproduction, potentially leading to region-wide recruitment failure (3). (B) Managing coral reefs in an era of rapid climate change requires action at multiple levels of governance to address drivers of coral decline that emerge from human activities at different spatial scales. Note that management at all levels will be most effective if enacted early. OA: ocean acidification sible for initial mortality are likely operating to prevent coral recovery (i.e. resilience of the coral system has been lost). Thus, the factors limiting the recovery of corals will often be different from those that initially caused their decline. Where chronic anthropogenic impacts such as sedimentation or nutrient loading have led directly to coral decline, eliminating those impacts will be necessary to facilitate coral recovery. However, because feedbacks can prevent coral recovery even after the initial causes of coral decline have been removed, intense management intervention may also be required to break feedbacks that operate to slow or prevent coral recovery. A number of feedbacks may prevent coral recovery on Caribbean reefs, and many of these are directly dependent on the ability of herbivores to control algae (Fig. 1).

One of the key feedbacks that likely reinforces an algae-dominated state is the dilution of grazing intensity as corals decline and create large amounts of space for the establishment of benthic algae (Williams et al. 2001, Paddack et al. 2006, Mumby et al. 2007). Even in the absence of fishing pressure, loss of corals will decrease grazing intensity as herbivores graze over a larger area of reef. Macroalgae that were once excluded under higher grazing pressure may then become established. This can result in a reef shifting from a state dominated by early successional stages of highly palatable and productive algal turfs to a state dominated by later successional stages of less palatable and less productive macroalgae (e.g. Carpenter 1986). Dense stands of macroalgae can deter herbivory (Hoey \& Bellwood 2011) and prevent the reestablishment of corals by inhibiting coral recruitment (Birrell et al. 2008). Over longer time scales, declines in coral cover will reduce habitat complexity, potentially reducing habitat for fishes and driving declines in herbivore populations (Graham et al. 2006, Paddack et al. 2009, Adam et al. 2014), further reinforcing the shift to an algae-dominated state. Finally, as coral decline becomes more spatially extensive, coral populations will reach 
critically low densities, limiting their ability to successfully reproduce and ultimately leading to regionwide recruitment failure (Knowlton 1992, Hughes \& Tanner 2000). While all of these processes (and others) may operate to inhibit coral recovery on many Caribbean reefs, the relative importance of each is unknown and will likely depend strongly on environmental context. Managing herbivores to facilitate corals requires that we can identify when and where particular feedbacks are operating to reduce herbivory and/or prevent coral recovery.

How does the frequency, intensity, and scale of disturbance mediate the impacts of herbivores on reef dynamics?

Coral reef ecosystems vary widely in their susceptibility to natural disturbances. At one extreme, many shallow, exposed reefs undergo rapid cycles of disturbance and recovery, routinely losing almost all of their coral cover every decade or so due to tropical cyclones (e.g. Connell et al. 1997, Trapon et al. 2011). At the other end of the spectrum, massive coral colonies growing in less disturbance-prone locations can live hundreds of years without being severely impacted by disturbance (e.g. Brown et al. 2009). Because disturbances result in the rapid liberation of space for the establishment and growth of benthic algae, herbivores may be more important on reefs frequently subjected to intense disturbances (e.g. Adam et al. 2011). In addition, some herbivores may be more capable of responding rapidly to increases in algae and therefore may be particularly important for preventing persistent phase shifts on disturbanceprone reefs (see Questions 2 and 3).

One of the most important consequences of global climate change (GCC) for herbivore-algae-coral interactions will be an increase in the frequency, severity, and spatial scale of disturbances caused by mass bleaching events (Hoegh-Guldberg et al. 2007). During the past 2 decades, reefs throughout the Caribbean basin have experienced warm water events that are unprecedented in at least the last $150 \mathrm{yr}$, with major bleaching episodes in 1998 and again in 2005 (Eakin et al. 2010). Both events caused severe coral decline on the most heavily impacted reefs (e.g. Aronson et al. 2002, Whelan et al. 2007, Miller et al. 2009). As global $\mathrm{CO}_{2}$ emissions continue to increase, coral bleaching is expected to become an even greater threat to coral reefs in the future (Donner et al. 2007, Hoegh-Guldberg et al. 2007). Increases in the frequency and severity of bleaching will also interact with chronic environmental drivers such as ocean acidification that will slow coral growth (Hofmann et al. 2010) and potentially increase the competitive abilities of algae relative to corals (Diaz-Pulido et al. 2011).

While herbivores may be able to offset the impacts of GCC to some degree, the resilience of reefs will depend in part on the availability of coral larvae to recolonize reefs following major disturbance events. Reefs which are less prone to disturbance-such as those occurring in deep water or in upwelling zones where cool water can prevent coral bleaching-will likely be important refugia for some coral species and may be important sources of larvae for recolonizing impacted reefs following large bleaching events (Bongaerts et al. 2010, Bridge et al. 2013, Chollett \& Mumby 2013). Projected increases in disturbance due to GCC highlight the need to manage reefs for resilience by maintaining healthy herbivore populations. However, these management actions will only be effective if we can identify and conserve reefs that can act as a source of coral recruits following catastrophic disturbances. Herbivory will matter little if there are too few corals present to produce larvae to colonize disturbed reefs. Thus, it will be important to identify reefs that are more/less prone to disturbance in order to appropriately focus management efforts.

How does water quality mediate the herbivore-algae-coral interaction?

Coastal pollution has likely been an important driver of coral decline throughout much of the Caribbean. Poor land-use practices associated with agriculture and urban development increase the delivery of sediments, nutrients, and a wide range of contaminants to near-shore ecosystems (Fabricius 2005). In addition, large amounts of nutrients, organic contaminants, and harmful microbes are introduced to coral reefs directly through the disposal of sewage (e.g. Lipp et al. 2002, Lapointe et al. 2005). Collectively, these factors reduce water quality and adversely affect reef-building corals via both direct and indirect pathways (Fabricius 2005). Increases in nutrients can have direct negative effects on corals by decreasing their growth rates (Shantz \& Burkepile 2014) and increasing the prevalence of coral disease and bleaching (Vega Thurber et al. 2014), as well as indirect effects by increasing growth rates of their algal competitors (Jompa \& McCook 2002). Thus, like many stressors, impacts of nutrient pollution on corals are complex and operate through a variety of different 
pathways. It is likely that herbivores can offset some of these negative impacts by consuming excess algal production, but they may have limited effects on others, such as those leading to coral bleaching and disease.

In addition, multiple stressors often interact in complex non-linear ways such that the impact of any single stressor is contingent on the presence of others. For example, sedimentation is a major stressor on coral reefs that can lead to coral decline by smothering and killing adult corals and can impede coral recovery by preventing the successful recruitment of coral larvae (Rogers 1990). By trapping sediments, algal turfs can interact with sedimentation to increase coral mortality, reduce coral growth, and impede coral settlement (Nugues \& Roberts 2003, Birrell et al. 2005, Gowan et al. 2014). Fishing could therefore act synergistically with sedimentation to suppress corals by reducing herbivory and allowing the development of mats of sediment-trapping algal turfs. However, once sedimentation levels become sufficiently high, sediments will begin to smother and kill corals regardless of the presence of algae (e.g. Nugues \& Roberts 2003), negating any positive impacts of herbivores.

The previous example illustrates that management actions targeted at increasing levels of herbivory are likely to benefit reefs greatly over some ranges of stressors but relatively little or not at all once those stressors reach some upper threshold level. A better mechanistic understanding of how corals and their symbionts respond to multiple stressors, including nutrients, sediments, increases in temperature, and competition with algae, will help identify the factors that limit coral populations. By identifying the factors most strongly limiting corals, managers will be able to more efficiently allocate limited resources to promote coral persistence and recovery by targeting the specific locations that are most likely to benefit from particular management interventions, such as protection of herbivorous fishes.

How do the effects of herbivores on coral and algae vary with productivity?

The standing stock of algae on a coral reef represents a dynamic balance between algal production and mortality, with more grazing needed to control algae on highly productive reefs. Productivity of algae on many shallow coral reefs is likely limited by the availability of nutrients (nitrogen, phosphorus, and micronutrients such as iron; McCook 1999).
Large-scale differences in nutrient availability occur within and among ocean basins (Kleypas et al. 1999), and these differences may influence the level of herbivory necessary to control algae across geographic regions. Indeed, high levels of algal production on Caribbean reefs may make these reefs more susceptible to coral-algal phase shifts compared to many Pacific reefs (Roff \& Mumby 2012).

While regional differences in productivity are important for understanding the capacity of herbivores to control algae, productivity also varies greatly on much smaller spatial scales. For example, turbulent reef zones (e.g. shallow exposed forereefs) are generally more productive than calmer reef zones (e.g. lagoonal backreefs and fringing reefs; Falter et al. 2004), and shallow, well-lit reefs are more productive than deeper reefs (Carpenter 1985). Reefs in more productive environments may be less resilient to disturbances due to their capacity to support rapid algal growth. However, herbivorous fishes strongly track spatial variation in productivity across the reef landscape, such that grazing intensity is often highest in the most productive habitats (Van den Hoek et al. 1978, Russ 2003, Fox \& Bellwood 2007). Indeed, on Caribbean reefs, macroalgae are often least abundant in shallow locations and more abundant in deeper, less productive habitats where grazing pressure is lower (Hay et al. 1983, Morrison 1988, Bruggemann et al. 1994b). In addition, because corals can also be limited by light and flow, shallow reefs often support the highest capacity for coral growth and reef accretion (Schlager 1981). Thus, management efforts to maintain herbivory may have the biggest impacts on shallow reefs where the capacity for both algae and coral growth are often the highest.

How does the outcome of herbivore-algae-coral interactions vary among different reef zones and habitats?

Prior to recent collapse of coral populations, coral reefs throughout the Caribbean exhibited distinct zonation patterns, with the major framework-building corals found in characteristic reef zones determined by physical factors such as exposure, depth, and distance from shore (Jackson 1991). In general, the coarse-branching coral Acropora palmata dominated reef crests and shallow spur and groove reefs, the fine-branching $A$. cervicornis dominated middepth forereefs, and massive Montastraea spp. dominated deeper forereefs, with both $A$. cervicornis and Montastraea forming lagoonal patch reefs (e.g. 
Goreau 1959, Adey \& Burke 1976, Geister 1977). While these reef zones appear to be highly deterministic, physical factors such as depth and exposure can interact in complex ways to modify patterns from location to location (Geister 1977). Therefore, sitespecific historical information on the distribution of different coral species will be invaluable for managers when determining places for targeted restoration.

A large fraction of hard-bottom habitat throughout the Caribbean is relatively flat limestone pavement dominated by gorgonians, sponges, and/or calcifying and non-calcifying algae. While these habitats are often not suitable for the growth of major frameworkbuilding corals, they can support abundant and diverse fish communities and contribute significantly to fisheries production (Wolff \& Grober-Dunsmore 1999, Garrison et al. 2004). Integrating information on the physical factors influencing the distribution of corals with knowledge of the ecological impacts of herbivores could create opportunities for spatial management strategies that can limit trade-offs between different management goals (such as sustaining a fishery while also maintaining high grazing rates to control algae and facilitate corals). For example, fisheries managers may be able to limit the take of herbivorous fishes on structurally complex reefs while allowing fishing of herbivores in the low-relief habitats which appear to be largely unsuitable for major framework-building corals (Mumby 2015). Integrating knowledge about the current and historical distributions of major framework-building corals could allow for targeted management actions aimed at facilitating coral recovery (including augmenting herbivory) in the locations where corals are mostly likely to benefit.

\section{Question 2. What level of herbivory is needed to control algae and how important is herbivore diversity and identity?}

Most experiments testing the impacts of herbivores on benthic communities on coral reefs have used exclusion cages to compare treatments with and without ambient levels of herbivory (e.g. Lewis 1986, Miller et al. 1999, Hughes et al. 2007). These experiments have demonstrated that algae are controlled by top-down forces (e.g. Burkepile \& Hay 2006), but they do little to determine the level of herbivory needed to control algae or to differentiate impacts of different types of herbivores. The fact that algae are abundant on many Caribbean reefs suggests that current levels of herbivory are too low to adequately control algae, and exclusion experiments do little to inform us how much more herbivory is required.

Determining the amount of herbivory needed to suppress algae is further complicated by the speciesspecific impacts that herbivores have on algal communities. Early studies investigating how different herbivores affect Caribbean reefs focused on fishes versus D. antillarum (Carpenter 1986, Morrison 1988). These studies found that $D$. antillarum can suppress a wide variety of filamentous turf algae and macroalgae, many of which are apparently unpalatable to fishes. However, recent studies indicate that there are also large functional differences among herbivorous fishes (Burkepile \& Hay 2008, 2010, 2011). Using experimental enclosures to partition the effects of different fishes, Burkepile \& Hay $(2008,2010)$ found that different species of fishes had unique and complementary impacts on algal communities, with the relative importance of each depending on the successional state of the community. The parrotfish Sparisoma aurofrenatum controlled macroalgae in communities with high existing cover of macroalgae, while the parrotfish Scarus taeniopterus and surgeonfish Acanthurus bahianus suppressed filamentous algal turfs and prevented the establishment of macroalgae in early successional stage communities. Because upright macroalgae and filamentous turfs both have negative effects on corals, no single species was capable of preventing the spread of harmful algae and facilitating coral recruitment and growth. Thus, herbivore diversity appears to be critical for maintaining ecosystem function. Understanding the importance of herbivore diversity and identity in complex species-rich coral reef ecosystems requires greater knowledge of patterns of complementarity for the entire herbivore guild. Herbivores that feed on different types of algae are likely to be complementary because they will control algae that can dominate in different places or at different points in time. In contrast, herbivores with high overlap in diet are more likely to have similar impacts on algal communities and may therefore be functionally redundant.

Complementarity among herbivores is important for suppressing algae and facilitating corals, but functional redundancy may also confer resilience to reefs by making them less susceptible to the loss of a single species (Walker 1992). For example, when a species declines due to overfishing or disease, species with similar functions may be able to fill the vacated role in the herbivore guild. Thus, response diversity, when functionally redundant species respond differently to perturbations, is important for 
the resilience of an ecosystem (Elmqvist et al. 2003). Therefore, it is critical to determine the extent that herbivores with similar functions vary in their response to different types of perturbations.

Managing herbivores for their impacts on coral reef ecosystems requires knowledge of the specific roles played by particular species, and ultimately the levels of complementarity and response diversity present within the herbivore guild. Levels of complementarity will be a function of (1) the amount, types, and life stages of algae that different herbivores eat, (2) the habitats they select while foraging, and (3) the particular substrates they feed from within those habitats. Consequently, understanding the level of functional redundancy and complementarity present within the herbivore guild will require detailed information on the diet, foraging behavior, and grazing rates of individual species.

How are herbivore traits distributed across taxa?

Diet selection and feeding mode. Herbivorous fishes can be classified into functional groups according to their diet and feeding mode (Bellwood \& Choat 1990, Choat et al. 2004). These functional groups can help identify patterns of complementarity and redundancy within the herbivore guild in order to predict the unique impacts of different herbivore species on coral reef ecosystems (Bellwood et al. 2004, Bonaldo et al. 2014). Unfortunately, a functional group framework has not been well-developed for herbivores on Caribbean reefs. While Caribbean reefs have lower herbivore diversity than many Pacific reefs, they still harbor over 3 dozen species of fish from 10 families and several species of sea urchins that feed primarily on algae and/or sea grass (Randall 1967).

Quantitative data on the diets of most Caribbean herbivores are rare, but we can make some generalizations. Parrotfishes (Scaridae), surgeonfishes (Acanthuridae), and the sea urchin $D$. antillarum are likely the most important herbivores in the region based on their abundance, size, and feeding behavior. While D. antillarum has a very wide diet breadth (Ogden 1976), most herbivorous fishes are more selective, with specific feeding preferences likely driven by a variety of algal traits (e.g. chemical and physical defenses and nutritional content; Hay 1997). Parrotfishes in the genus Sparisoma tend to browse macroalgae, while those in the genus Scarus primarily target turf algae (Randall 1967, Lewis 1985, McAfee \& Morgan 1996, Burkepile \& Hay 2010). In contrast, the 3 species of surgeonfishes, Acanthurus bahianus, $A$. chirurgus, and A. coeruleus, appear to target a combination of turf algae, detritus, and macroalgae (Randall 1967, Lewis 1985, Burkepile \& Hay 2011). These observations suggest some level of complementarity and redundancy within and between the major groups of herbivores on Caribbean reefs, but more detailed data on the specific types of algae targeted by these herbivores are needed.

In addition to diet preferences, we also need information about grazing rates of individual species. Grazing capacity of herbivores can be estimated based on bite rate data combined with algal yield per bite, or extrapolated from models that scale the metabolic requirements of herbivorous fishes to their body size (e.g. van Rooij et al. 1998, Mumby 2006, Paddack et al. 2006). The relationship between fish mass and grazing capacity is likely a non-linear, decelerating function. The result is that biomass-specific grazing rates may in fact be greater for smaller fish, which agrees with both metabolic theory (West et al. 1997) and field data on the grazing capacity of Sparisoma viride (van Rooij et al. 1998). However, there are specific functions, such as bioerosion and the removal of some types of macroalgae, that are only achieved by large fishes (Bellwood et al. 2012). Thus, altering the size structure of herbivore populations, without altering overall biomass of fishes, may fundamentally alter the grazing capacity of the herbivore guild. Future research should address how different metrics of grazing capacity (e.g. consumption of different types of algae, bioerosion, areal grazing rates, etc.) change as a function of the size structure and species composition of the herbivore guild. These data will be critical for understanding how fishing impacts the grazing capacity of the herbivore guild via changes in the size structure and abundance of fish assemblages.

In addition to exhibiting preferences for particular types of algae, herbivores use a variety of feeding modes that will influence benthic communities differently. For example, many surgeonfish feed by cropping algal filaments, while many parrotfish and sea urchins scrape or excavate the substrate (Bellwood et al. 2004). Parrotfishes and sea urchins often remove part of the calcium carbonate reef framework in addition to epilithic algae, thereby also removing all algal tissue and inhibiting algal regrowth. Consequently, parrotfish and sea urchins often open up new space that can be colonized by crustose coralline algae and/or coral. However, bioerosion by parrotfishes and sea urchins also impacts the long-term dynamics of coral and fish habitat by influencing the balance between reef accretion and erosion (reviewed 
by Glynn 1997). Bioerosion by sea urchins and parrotfishes often accounts for a major fraction of the calcium carbonate budget on a coral reef, and high rates of erosion combined with moderate or low levels of accretion (like those currently experienced on many Caribbean reefs) can result in the net erosion of the reef structural framework with cascading indirect effects on corals and fishes that depend on the architectural complexity of reef habitats (Perry et al. 2013). In addition, bioerosion by fish and sea urchins could be magnified by ongoing local and global anthropogenic drivers, such as nutrient enrichment and ocean acidification that will weaken the reef framework (Hallock 1988, Manzello et al. 2008, Wisshak et al. 2012).

$S$. viride is likely the most important bioeroding fish on Caribbean reefs. S. viride is functionally unique among the Sparisoma parrotfishes, targeting endolithic algae by using its strong jaws and hard teeth to excavate the substrate (Bellwood 1994, Bruggemann et al. 1996, Streelman et al. 2002). Direct estimates of bioerosion by $S$. viride indicate that where abundant, they can erode several $\mathrm{kg}$ of carbonate material $\mathrm{m}^{-2} \mathrm{yr}^{-1}$ (Bruggemann et al. 1996), an amount that is similar to that removed by very high densities of the sea urchin $D$. antillarum (Ogden 1977). While $S$. viride removes much more carbonate material than other similar sized parrotfishes such as Scarus vetula, the amount of carbonate material removed by an individual parrotfish increases with body size. Thus the 2 largest parrotfishes in the Caribbean, S. guacamaia and S. coelestinus, are likely important bioeroders on the reefs where they occur. However, no published estimates of erosion by these fishes exist, and little is known about their basic feeding preferences, foraging habits, and historical abundance.

Many scraping and excavating parrotfishes, and some sea urchins, also feed on benthic invertebrates including coral (Bak \& Eys 1975, Sammarco 1980, Miller \& Hay 1998, Burkepile 2012). Sea urchins and parrotfishes can both kill small coral recruits, and some parrotfishes, such as $S$. viride, can kill large coral colonies (e.g. Bruckner \& Bruckner 1998, Rotjan \& Lewis 2005). Other Caribbean parrotfishes, including Scarus vetula, S. guacamaia, and Sparisoma aurofrenatum also feed on live coral (Rotjan \& Lewis 2008). No studies to date have quantified the relative contribution of different species to the total level of corallivory occurring on Caribbean reefs. Yet recent studies indicate that total predation intensity by parrotfishes on corals could increase as coral density declines (Burkepile 2012), potentially creating a feedback that could prevent coral recovery (Glynn 1985, Knowlton et al. 1990, Jayewardene et al. 2009). Therefore, understanding the direct negative impacts of parrotfish on corals is a major priority, especially on reefs that already have low coral cover.

Spatial patterns of herbivory. The scale over which herbivores move and the habitats they select while foraging will influence how their grazing impacts are distributed in space. Herbivores that forage over different spatial scales can have fundamentally different impacts on benthic communities. For example, recent modeling work suggests that the high intensity, spatially constrained foraging behavior of the sea urchin $D$. antillarum is more likely to facilitate coral recruitment and coral dominance than the more spatially diffuse herbivory of large, roving fishes (Sandin \& McNamara 2012). However, herbivorous fishes also vary greatly in how they use space (e.g. Nash et al. 2013), and we know little about the foraging scales of most herbivorous fishes in the Caribbean.

Herbivorous fishes also feed in different habitats and target different substrates (Hay 1985, Robertson \& Gaines 1986, Bellwood \& Choat 1990, Bruggemann et al. 1994a, Brandl \& Bellwood 2014). Because habitat quality for corals varies greatly in space, these foraging choices will influence how herbivores impact coral recruitment and growth. Understanding how herbivores affect coral persistence and recovery will therefore require knowing precisely where different species of herbivores are exerting their impacts in addition to knowing the types of algae they are eating.

Are some grazers more important than others?

For years, coral reef scientists have debated whether fishes or sea urchins are more important for controlling algae and facilitating corals on Caribbean reefs. This question is complex and the answers have been shaped by where research has been done. For example, much of the work on the impacts of D. antillarum on algae and corals was conducted on reefs with sustained heavy fishing pressure (e.g. Jamaica: Sammarco 1982, Morrison 1988; Virgin Islands: Carpenter 1986). Hay (1984) suggested that the importance of $D$. antillarum may have been overestimated by studies in places with few herbivorous fishes or $D$. antillarum predators. He showed that most herbivory was from fishes in areas with minimal fishing pressure while urchins were most important in areas with high fishing (see also Jackson et al. 2014). Historically, reefs in the Caribbean may have 
had relatively more herbivory from fishes and less herbivory from urchins than was documented shortly before the $D$. antillarum die-off in the early 1980s. This suggests that $D$. antillarum may have been the most important herbivore in many parts of the Caribbean, not because fish were incapable of performing the same ecological function, but rather because $D$. antillarum provided a level of response diversity to fishing (i.e. fishing had indirect positive effects on $D$. antillarum, causing it to increase in abundance while other herbivores were fished out).

This is not to say that $D$. antillarum are unimportant. Coral recovery has coincided with recovery of $D$. antillarum in recent years, strongly supporting the idea that $D$. antillarum are important for coral recovery in the Caribbean (Edmunds \& Carpenter 2001, Carpenter \& Edmunds 2006, Myhre \& Acevedo-Gutiérrez 2007, Furman \& Heck 2009, Idjadi et al. 2010). D. antillarum have several traits that may make them particularly effective herbivores, including having a wide diet breadth (Ogden 1976), a scraping/excavating feeding mode (Ogden 1977), and foraging behavior that results in intensive grazing over a very small spatial scale (Carpenter 1984). Thus, the functional impact of many different species of fishes was likely approximated well by 1 species of urchin, at least for a limited amount of time. Nonetheless, the catastrophic impact of the D. antillarum die-off on many Caribbean reefs highlights the danger of relying on a single species to perform a critical ecological function.

Given that $D$. antillarum have not recovered following their mass mortality in most places across the Caribbean, it is critical to identify which combinations of herbivorous fishes can facilitate coral persistence and recovery in its absence. It is likely that a different suite of herbivores is needed to facilitate coral recovery on degraded reefs compared to those that can maintain the resilience of intact reefs. Species that feed on adult macroalgae are likely to be particularly important for reversing phase shifts on macroalgae-dominated reefs. These include macroalgaebrowsing parrotfishes in the genus Sparisoma, as well as other browsing herbivores such as chubs (Kyphosidae). Knowledge of the diets and feeding behaviors of different herbivores is an important first step in predicting their impacts on coral persistence and recovery. However, predictions of ecological function based on behavioral and morphological traits will be most powerful when combined with mechanistic models (e.g. Sandin \& McNamara 2012) and field experiments (e.g. Burkepile \& Hay 2008, 2010) that can better determine the combined impacts of multiple herbivore species.

\section{Question 3. What limits the process of herbivory on coral reefs?}

Many of the feedbacks that could prevent coral recovery in the Caribbean and elsewhere operate through their impacts on herbivory (Fig. 1). Therefore, understanding what limits herbivory is essential for predicting how these ecosystems will respond to acute and chronic perturbations, including coral bleaching events, anthropogenic nutrient loading, and fishing. Feedbacks impacting herbivore-algaecoral interactions are realized over a range of spatial and temporal scales. While some feedbacks originate from changes in the behavior of individual herbivores, others occur due to longer-term impacts on population dynamics that operate over large spatial scales. Consequently, understanding what limits the process of herbivory on coral reefs will require a synthetic approach that integrates information on individual behavior with population-level data. Herbivore populations will be limited by a combination of top-down and bottom-up processes, with predators and resources also impacting individual behavior.

To what extent is herbivory limited by fishing, natural predation, and disease?

Top-down impacts of human exploitation on coastal marine ecosystems are pervasive (Jackson et al. 2001). Humans have been exploiting near-shore environments of the Caribbean for thousands of years, and hunting of megaherbivores (sea turtles and manatees) during the past several centuries has reduced their abundance by orders of magnitude (Jackson 1997). Archeological records from sites across the Caribbean indicate that herbivorous reef fishes, especially parrotfishes, have been heavily fished in some locations for thousands of years (reviewed by Fitzpatrick \& Keegan 2007). Comparisons of fish fauna of inhabited versus uninhabited islands in the Indo-Pacific demonstrate that even low levels of exploitation can rapidly deplete stocks of large fishes, including herbivorous parrotfishes (e.g. Friedlander \& DeMartini 2002, Bellwood et al. 2012). Given the high levels of current and historical fishing throughout much of the Caribbean and the observation that even low levels of fishing can limit the populations of larger, slower-growing species, fishing is almost certainly a major factor limiting the abundance of large parrotfishes in many locations. Indeed, the largest species in the Caribbean, Scarus guacamaia, S. coelestinus, and S. coeruleus, are rare 
or absent on most reefs (Hawkins \& Roberts 2003, Kramer 2003) and are most abundant in places with little or no fishing pressure (Debrot et al. 2008, Comeros-Raynal et al. 2012). In addition, biomass of intermediate-sized parrotfishes, such as Sparosoma viride and Scarus vetula are negatively correlated with fishing pressure across much of the region (Hawkins \& Roberts 2003).

While some herbivore species are likely limited by fishing throughout large parts of the Caribbean, it is less clear how their loss impacts the total level of herbivory on these reefs. For example, smaller-bodied species may increase in abundance as they are released from competition or predation, potentially compensating for the loss of larger species (Hay 1984, Dulvy et al. 2004, Clua \& Legendre 2008). Nonetheless, different herbivore species and size classes have distinct diet preferences and feeding modes, and thus they are unlikely to perform the same ecological functions (see above). Therefore, it is critical to identify which herbivore traits are unique amongst species most susceptible to fishing, and how lack of redundancy in these traits will impact ecosystem function. Finally, while low to moderate levels of fishing can lead to the functional elimination of many larger-bodied herbivore species, it is less clear what levels of fishing are sustainable for most other species.

In addition to being heavily exploited by humans, herbivorous fishes and sea urchins are preyed upon by a wide variety of predatory fishes (Randall 1967). Predators can have large impacts on the structure and function of natural ecosystems via their consumptive effects on prey populations and cascading indirect effects on the resources of their prey (e.g. trophic cascades). However, predators also strongly impact prey traits (e.g. behavior, growth, and reproduction), and recent research indicates that these non-consumptive effects (NCEs) frequently have farreaching ecosystem-level consequences (Dill et al. 2003, Peckarsky et al. 2008, Schmitz 2008).

NCEs arise due to inherent trade-offs between the need to eat while avoiding being eaten. As a result of these trade-offs, prey often allocate less time to foraging or shift activity to safer but less profitable habitats when predation risk is high (Lima \& Dill 1990). NCEs may be of considerable importance in coral reef habitats, where high structural complexity offers many refugia, potentially increasing the ability of prey to respond behaviorally to their predators. In both the Caribbean and Pacific, herbivorous sea urchins and fishes often concentrate their grazing around the edges of large patch reefs where they can find shelter from their predators. Grazing pressure around the perimeter of these reefs can be so intense that it creates distinct 'grazing halos' easily seen in aerial photographs and satellite images (Randall 1965, Ogden et al. 1973, McManus et al. 2000, Madin et al. 2011).

Recent research on reefs in the central Pacific suggests that enhanced predation risk may also cause herbivorous fishes to restrict their foraging ranges on continuous reefs, thereby affecting the spatial distribution of algae and potentially modifying coral-algal competition (Madin et al. 2010). This work suggests the possibility that predators could create heterogeneous landscapes where hotspots of grazing activity create habitat suitable for coral recruitment. Thus, in contrast to predictions from classic trophic cascades, where predators of herbivores would be expected to have negative effects on corals by releasing algae from top-down control, incorporating impacts of predators on herbivore behavior suggests that predators could have indirect positive effects on corals through their influence on the spatial patterning of herbivory. It is only recently that coral reef scientists have started to link behavioral changes in prey to predation risk (e.g. Catano et al. 2014), yet understanding how predators impact habitat use, foraging rate, and the spatial scale of foraging of different herbivore species will be important for predicting the impacts of fishing on ecosystem function on coral reefs.

In addition to being preyed upon whole, many reef fishes are preyed upon by parasites, including those that cause infectious disease. Parasites are difficult to sample, and their impacts on host populations are difficult to quantify; thus, the role of parasites in limiting many animal populations is largely unknown (Tompkins et al. 2011). Many of the parasites that affect reef fishes are likely to have important impacts on their population dynamics and behavior. For example, parrotfishes in both the Indo-Pacific and Caribbean spend a significant fraction of their daily time budget visiting 'cleaner stations', where they have their ectoparasites removed by specialized cleaner fish and shrimps (Soares et al. 2013). Thus, the distribution of cleaners may create hotspots of activity for herbivorous and corallivorous fishes which in turn may indirectly affect coral and algae (Adam 2012).

Microbes that cause infectious disease are often difficult to identify, yet they can have overwhelmingly large impacts on the functioning of entire ecosystems. The die-off of $D$. antillarum and the cascading indirect effects on Caribbean reefs was apparently a result of infectious disease that spread quickly through- 
out the entire Caribbean basin (Lessios 1988). While the causative agent in the $D$. antillarum epidemic has never been identified, the outbreak may have been exacerbated by unusually high densities of the urchin due to the elimination of its predators and competitors. Infectious disease appears to be a common cause of boom and bust dynamics in other echinoderms (Uthicke et al. 2009), suggesting that relying on urchins to be the primary herbivores on reefs may set the stage for repeated, catastrophic losses of herbivore populations. Because disease agents are usually specific to particular taxa and transmission is positively density-dependent, other herbivore species could also become vulnerable to infectious disease if their populations experience large increases in response to removal of their predators and/or competitors. Unfortunately, because we know little about infectious disease in marine organisms, future epidemics will almost certainly come as a surprise.

Are herbivore populations limited by the availability of juvenile habitat?

Like many foundation species, corals provide physical habitat for other organisms. Branching corals in particular serve as important habitat for juvenile fishes, including herbivores, that shelter in and around corals to escape from their predators. Many reef fishes selectively use live branching corals as recruitment habitat and could become vulnerable to habitat loss as corals decline (Tolimieri 1998, Jones et al. 2004, Adam et al. 2011). However, fish can also gain refuge in other common reef substrates, including macroalgae and sponges, and many fishes are likely to have some level of plasticity in microhabitat selection. For example, in the Florida Keys, $S$. viride successfully uses the abundant macroalgae Dictyota spp. as recruitment substrate in the absence of preferred branching corals (Paddack \& Sponaugle 2008). Nonetheless, the capacity of most fishes to recruit to different microhabitats is unknown. In fact, surprisingly little is known about recruitment habitat requirements of several species of Caribbean parrotfishes (e.g. Scarus coelestinus, S. coeruleus, and $S$. guacamaia). Clearly, successfully managing herbivore populations requires a better understanding of their basic habitat requirements.

While some herbivorous fishes are strongly reefassociated throughout their ontogeny, several Caribbean parrotfishes (e.g. S. iseri, S. guacamaia, $S$. coeruleus, Sparisoma chrysopterum) use off-reef nursery habitats such as sea grasses and mangroves before migrating to coral reefs as large juveniles or adults (Nagelkerken et al. 2000, 2002, Mumby et al. 2004, Machemer et al. 2012). Thus, it is possible that these species are limited by the availability of juvenile nursery habitat. For example, the largest herbivorous fish in the Caribbean, S. guacamaia, appears to depend on mangroves during its juvenile phase, and mangrove clearing may have led to its local extinction on an isolated atoll in Belize (Mumby et al. 2004). The fact that many herbivorous fishes use nonreef habitats as juveniles presents both opportunities and challenges for management. While management efforts often focus on a single habitat, connectivity between different habitats should enhance the resilience of coral reefs by providing reefs with a source of herbivores following localized coral decline (Adam et al. 2011). However, we know relatively little about the dependence of particular herbivore species on specific nursery habitats and even less about the scale of movement that occurs among habitats. Spatial planning efforts, including the implementation of marine reserves, could benefit tremendously from better information on habitat utilization across life history stages and the scale of movement of different herbivore species.

How do food availability and quality shape herbivore abundance and behavior?

Models linking herbivory to the resilience of coral reefs often begin with the assumption that herbivores are limited by top-down forces, yet herbivores may be food limited (van Rooij et al. 1998). Indeed, timeseries data increasingly suggest that herbivores can be limited by food, even in locations with moderate to high levels of fishing. For example, recent observations of reefs in the Caribbean and Indo-Pacific have revealed that herbivorous fish can experience large increases in abundance and biomass in response to the increase in turf algae that accompanies a rapid decline in coral (Hawkins et al. 2006, Adam et al. 2011, Gilmour et al. 2013). Similarly, Carpenter (1990) observed large increases in the abundances of juvenile parrotfish and surgeonfish in the US Virgin Islands shortly after the Diadema die-off, suggesting that these fish had been limited at least in part by competition for algae with Diadema.

Counter-intuitively, herbivores may be food-limited even on algae-dominated reefs since macroalgae are frequently physically and chemically defended and can exclude more palatable filamentous turf algae (e.g. McClanahan et al. 2000). Thus, as reefs become 
dominated by unpalatable macroalgae, they may shift to a detrital based food-web with much of the macroalgae going uneaten by herbivorous fishes, potentially transferring energy away from reef fishes and other herbivores (Carpenter 1986). Increasing herbivore food limitation would further reinforce an algae-dominated state. This suggests that in order to avoid a persistent phase shift to an algae-dominated state, herbivores would need to respond rapidly to increases in algal production caused by the liberation of space for algal growth following a major disturbance (Scheffer et al. 2008, Adam et al. 2011, Blackwood \& Hastings 2011). While herbivores can respond behaviorally to increased production on short time scales, rates of population change will be slower and will depend on growth rates, generation times, and the scale of self-recruitment, all of which will vary among species and locations.

When are herbivore populations likely to be limited by larval supply?

The availability of larvae can determine patterns of recruitment of reef fishes. The processes controlling larval supply of reef fishes are complex, involving a combination of biological processes that determine reproductive output and initial larval quality, and oceanographic processes that shape larval transport and nourishment (Cowen et al. 2006). The continued failure of $D$. antillarum to recover after the 1982-1983 mass mortality event is likely a result of insufficient larval availability due to an Allee effect limiting reproductive output (Lessios 2005). Recruitment failure of herbivorous fishes has not been reported, but little is known about the recruitment dynamics of many species, and recruitment on some heavily fished reefs is potentially persisting due to upstream sources of larvae (Cowen et al. 2006). Given the low abundances of many species of larger parrotfishes on most Caribbean reefs, it would not be surprising if these species were limited by larval supply in some locations. To avoid recruitment failure in the future, we need more information on the relationship between local adult density and larval connectivity to identify threshold levels of adult biomass and vulnerable areas.

\section{SUMMARY}

Herbivores control algae that otherwise have negative impacts on the recruitment, growth, and survivorship of reef-building corals. Consequently, we expect that enhancing herbivore populations should increase the resilience of coral-dominated reefs and facilitate coral recovery on degraded reefs. However, impacts of herbivores will vary greatly in space and time, and understanding when and where herbivores will be most important for facilitating coral persistence and recovery requires a better mechanistic understanding of the multiple processes that are currently limiting coral populations. This could be best achieved by forging stronger linkages between conceptual thinking, mathematical modeling, and empirical data.

For example, many of the conceptual arguments for strong positive indirect effects of herbivores on coral have focused on coral recruitment (e.g. Mumby \& Steneck 2008, Mumby et al. 2013). Yet, recent field-parameterized demographic models of 2 of the most important framework-building corals in the Caribbean, Montastrea annularis and Acropora palmata, indicate that ecologically relevant increases in recruitment rates cannot drive population recovery if the conditions limiting the growth and survivorship of adult colonies are not addressed (Edmunds \& Elahi 2007, Vardi et al. 2012). Factors limiting the growth of adult colonies are not well understood, but likely include interactions amongst a suite of chronic stressors, including increased water temperature, declining water quality, competition with algae, and in the case of $A$. palmata, chronic predation by corallivorous snails (Edmunds \& Elahi 2007, Vardi et al. 2012, Williams \& Miller 2012). While coral recruitment is clearly important for the replenishment of coral populations, demographic models underscore the need to better understand how macroalgae and filamentous turf algae limit the growth and survivorship of adult colonies (e.g. Lirman 2001, Vermeij et al. 2010), and especially how algae can interact with the multiple other stressors that impact coral growth and survivorship. These insights would allow us to better predict the extent that increases in herbivory can benefit corals facing a range of stressors.

In addition to knowing the role that algae play in limiting coral, we need to understand how diversity within the herbivore guild impacts algal assemblages. Mathematical models designed to predict coral and algae dynamics in response to local and global stressors have generally treated herbivores as a single functional group (e.g. Mumby 2006, Hoegh-Guldberg et al. 2007, Mumby et al. 2007, Anthony et al. 2011, Fung et al. 2011, Baskett et al. 2014). However, because herbivores performing different functions will exhibit a diversity of responses to anthropogenic stressors such as fishing (Bellwood et al. 2012, 
Edwards et al. 2014), this approach may be too simple. Empirical research should focus on identifying the ecological functions performed by different species of herbivores, and determine whether some functions are more susceptible to particular perturbations than others. Likewise, future modeling work aimed at predicting the impacts of anthropogenic stressors on coral persistence and recovery should explore the extent that complementarity and response diversity within the herbivore guild alter model predictions.

Developing effective management strategies to increase herbivory on Caribbean reefs requires identifying the factors limiting herbivore populations and the process of herbivory on particular reefs. Herbivore populations can be limited by a number of factors, including natural predation, fishing, food, the availability of juvenile habitat, and larval supply. Better information on larval connectivity and juvenile habitat associations in particular could facilitate management by helping managers identify and target key locations for protection. In addition, herbivores may avoid degraded reefs with high cover of macroalgae or low levels of physical structure, creating a reinforcing feedback that keeps herbivory low on degraded reefs even in locations with healthy herbivore populations. Thus, a better understanding of the behavioral responses of herbivorous fishes to coral decline, increases in algae, and the loss of structural complexity could aid efforts to restore reefs by identifying habitat characteristics that need to be restored to enhance grazing levels on reefs.

\section{MANAGEMENT RECOMMENDATIONS}

We currently have an incomplete understanding of the multiple factors limiting corals on Caribbean reefs. To complicate matters, many of these factors operate on regional or global scales managers cannot control. However, there are many actions that local managers can take. First, local management efforts should focus on minimizing direct sources of coral mortality, such as sedimentation and pollution, as well as restoring ecological processes, such as herbivory, that are important for coral persistence and recovery. Since nutrient loading can increase the severity and prevalence of coral disease and bleaching, reducing nutrient inputs may mitigate the negative impacts of ocean warming (e.g. Vega Thurber et al. 2014). Furthermore, reducing nutrient loading may also reduce algal productivity, facilitating the control of algae by herbivores.
Maintaining healthy herbivore populations is also likely to mitigate the negative impacts of ocean warming since abundant herbivores can control algae that inhibit coral recovery following coral decline (Edwards et al. 2011). Parrotfishes are particularly important herbivores on Caribbean reefs, but they also frequently support local fisheries. Therefore, complete bans on the harvesting of parrotfishes may not always be politically viable or economically desirable. However, better spatial management of fishing could minimize trade-offs between the need to maintain high levels of grazing while supporting sustainable fisheries. For example, managers could restrict fishing for herbivores on the reefs that are most suitable for major framework-building corals, while allowing fishing in other locations where corals are unlikely to benefit from herbivory (Mumby 2015). Effective spatial management requires detailed knowledge on the distribution of suitable habitat for different species of coral; at the coarsest level, this knowledge already exists in many locations in the Caribbean due to recent advances in remote sensing and large-scale efforts to map coral reef habitats (e.g. Pittman et al. 2013).

Implementation of marine protected areas or other spatial restrictions on herbivore fishing will only be effective if we can sustainably manage herbivore populations outside of protected areas. Different species of parrotfishes have different life-history traits and different impacts on benthic communities. Therefore, they should not be managed as a single species complex. In particular, the largest parrotfishes in the Caribbean, Scarus guacamaia, S. coelestinus, and $S$. coeruleus, are highly susceptible to overexploitation and are not functionally equivalent to smaller species, and thus should be fully protected from fishing. Further, Caribbean parrotfishes belong to at least 3 different functional groups (scrapers that feed primarily on turf algae, bioeroders that remove large amounts of carbonate material, and browsers that feed largely on upright macroalgae). Consequently, managers will need to ensure that reefs have the right mix of herbivores to carry out the full set of functions normally performed by the herbivore guild. Finally, it is critical to protect seagrasses and mangroves, which are important nursery habitats for several species of Caribbean herbivores.

While protection of herbivorous fishes is likely necessary for the maintenance of resilient coral reef systems, it is unlikely to be sufficient for the recovery of reefs, particularly where degradation has been severe and feedbacks are operating that could slow or prevent coral recovery. Under these conditions, 
management actions targeted specifically at breaking feedbacks that maintain reefs in a degraded state are necessary. Appropriate interventions are likely to be highly context-dependent. For example, in locations with high levels of fishing, restoration efforts aimed at augmenting densities of $D$. antillarum could be an important tool for increasing local grazing intensity on specific reefs. In contrast, in locations that are lightly fished, it may be more appropriate to focus on attracting herbivorous fishes by manually removing macroalgae, using artificial structures to increase habitat, or engaging in active restoration of corals. Restoration efforts targeted at specific reefs will be most successful under strong management of the wider seascape that limits chronic sources of coral mortality and protects key functional groups such as herbivorous fishes. Many of the feedbacks that prevent coral recovery may strengthen through time, so efforts to restore reefs likely have the highest chance of success (and will be least costly) when enacted early, before loss of living coral and structural complexity are severe.

Acknowledgements. This work was supported by a grant from NOAA's Coral Reef Conservation Program to D.E.B. and B.I.R. We thank M. W. Miller, J. Schull, and 2 anonymous reviewers for helpful feedback on an earlier version of this manuscript.

\section{LITERATURE CITED}

Adam TC (2012) Mutualistic cleaner fish initiate trait-mediated indirect interactions by influencing the behaviour of coral predators. J Anim Ecol 81:692-700

Adam TC, Schmitt RJ, Holbrook SJ, Brooks AJ, Edmunds PJ, Carpenter RC, Bernardi G (2011) Herbivory, connectivity, and ecosystem resilience: response of a coral reef to a large-scale perturbation. PLoS ONE 6:e23717

> Adam TC, Brooks AJ, Holbrook SJ, Schmitt RJ, Washburn L, Bernardi G (2014) How will coral reef fish communities respond to climate-driven disturbances? Insight from landscape-scale perturbations. Oecologia 176:285-296

Adey WH, Burke R (1976) Holocene bioherms (algal ridges and bank-barrier reefs) of the eastern Caribbean. Geol Soc Am Bull 87:95-109

> Adjeroud M, Michonneau F, Edmunds PJ, Chancerelle Y and others (2009) Recurrent disturbances, recovery trajectories, and resilience of coral assemblages on a South Central Pacific reef. Coral Reefs 28:775-780

> Alvarez-Filip L, Côté IM, Gill JA, Watkinson AR, Dulvy NK (2011) Region-wide temporal and spatial variation in Caribbean reef architecture: Is coral cover the whole story? Glob Change Biol 17:2470-2477

> Anthony KRN, Maynard JA, Diaz-Pulido G, Mumby PJ, Marshall PA, Cao L, Hoegh-Guldberg O (2011) Ocean acidification and warming will lower coral reef resilience. Glob Change Biol 17:1798-1808

Aronson RB, Precht WF (1997) Stasis, biological disturbance, and community structure of a Holocene coral reef. Paleobiology 23:326-346

Aronson RB, Precht WF (2006) Conservation, precaution, and Caribbean reefs. Coral Reefs 25:441-450

> Aronson RB, Precht WF, Toscano M, Koltes K (2002) The 1998 bleaching event and its aftermath on a coral reef in Belize. Mar Biol 141:435-447

Bak RPM, Eys G (1975) Predation of the sea urchin Diadema antillarum Philippi on living coral. Oecologia 20:111-115

> Baker AC, Glynn PW, Riegl B (2008) Climate change and coral reef bleaching: an ecological assessment of longterm impacts, recovery trends and future outlook. Estuar Coast Shelf Sci 80:435-471

Barott KL, Rodriguez-Mueller B, Youle M, Marhaver KL, Vermeij MJA, Smith JE, Rohwer FL (2012) Microbial to reef scale interactions between the reef-building coral Montastraea annularis and benthic algae. Proc R Soc Lond B Biol Sci 279:1655-1664

Baskett ML, Fabina NS, Gross K (2014) Response diversity can increase ecological resilience to disturbance in coral reefs. Am Nat 184:E16-E31

Bellwood DR (1994) A phylogenetic study of the parrotfish family Scaridae (Pisces: Labroidei), with a revision of genera. Rec Aust Mus 20 (Suppl):1-86

Bellwood DR, Choat JH (1990) A functional analysis of grazing in parrotfishes (family Scaridae): the ecological implications. Environ Biol Fishes 28:189-214

> Bellwood DR, Hughes TP, Folke C, Nyström M (2004) Confronting the coral reef crisis. Nature 429:827-833

> Bellwood DR, Hoey AS, Hughes TP (2012) Human activity selectively impacts the ecosystem roles of parrotfishes on coral reefs. Proc R Soc Lond B Biol Sci 279:1621-1629

> Birrell CL, McCook LJ, Willis BL (2005) Effects of algal turfs and sediment on coral settlement. Mar Pollut Bull 51: 408-414

Birrell CL, McCook LJ, Willis BL, Diaz-Pulido GA (2008) Effects of benthic algae on the replenishment of corals and the implications for the resilience of coral reefs. Oceanogr Mar Biol Annu Rev 46:25-63

> Blackwood JC, Hastings A (2011) The effect of time delays on Caribbean coral-algal interactions. J Theor Biol 273:37-43

Bonaldo RM, Hoey AS, Bellwood DR (2014) The ecosystem roles of parrotfishes on tropical reefs. Oceanogr Mar Biol Annu Rev 52:81-132

Bongaerts P, Ridgway T, Sampayo EM, Hoegh-Guldberg O (2010) Assessing the 'deep reef refugia' hypothesis: focus on Caribbean reefs. Coral Reefs 29:309-327

Box SJ, Mumby PJ (2007) Effect of macroalgal competition on growth and survival of juvenile Caribbean corals. Mar Ecol Prog Ser 342:139-149

> Brandl SJ, Bellwood DR (2014) Individual-based analyses reveal limited functional overlap in a coral reef fish community. J Anim Ecol 83:661-670

> Bridge TCL, Hughes TP, Guinotte JM, Bongaerts P (2013) Call to protect all coral reefs. Nat Clim Change 3: 528-530

Brown CJ, Mumby PJ (2014) Trade-offs between fisheries and the conservation of ecosystem function are defined by management strategy. Front Ecol Environ 12:324-329

> Brown DP, Basch L, Barshis D, Forsman Z, Fenner D, Goldberg J (2009) American Samoa's island of giants: massive Porites colonies at Ta'u island. Coral Reefs 28:735

- Bruckner A, Bruckner R (1998) Destruction of coral by Sparisoma viride. Coral Reefs 17:350 
Bruggemann JH, Kuyper MWM, Breeman AM (1994a) Comparative analysis of foraging and habitat use by the sympatric Caribbean parrotfish Scarus vetula and Sparisoma viride (Scaridae). Mar Ecol Prog Ser 112:51-66

> Bruggemann JH, van Oppen MJH, Breeman AM (1994b) Foraging by the stoplight parrotfish Sparisoma viride. I. Food selection in different, socially determined habitats. Mar Ecol Prog Ser 106:41-55

> Bruggemann JH, van Kessel AM, van Rooij JM, Breeman AM (1996) Bioerosion and sediment ingestion by the Caribbean parrotfish Scarus vetula and Sparisoma viride: implications of fish size, feeding mode and habitat use. Mar Ecol Prog Ser 134:59-71

Bruno JF, Sweatman H, Precht WF (2009) Assessing evidence of phase shifts from coral to macroalgal dominance on coral reefs. Ecology 90:1478-1484

Burkepile DE (2012) Context-dependent corallivory by parrotfishes in a Caribbean reef ecosystem. Coral Reefs 31:111-120

> Burkepile DE, Hay ME (2006) Herbivore vs. nutrient control of marine primary producers: context-dependent effects. Ecology 87:3128-3139

> Burkepile DE, Hay ME (2008) Herbivore species richness and feeding complementarity affect community structure and function on a coral reef. Proc Natl Acad Sci USA 105:16201-16206

> Burkepile DE, Hay ME (2010) Impact of herbivore identity on algal succession and coral growth on a Caribbean reef. PLoS ONE 5:e8963

> Burkepile DE, Hay ME (2011) Feeding complementarity versus redundancy among herbivorous fishes on a Caribbean reef. Coral Reefs 30:351-362

> Burkepile DE, Allgeier JE, Shantz AA, Pritchard CE, Lemoine NP, Bhatti LH, Layman CA (2013) Nutrient supply from fishes facilitates macroalgae and suppresses corals in a Caribbean coral reef ecosystem. Sci Rep 3: 1493

> Burman SG, Aronson RB, van Woesik R (2012) Biotic homogenization of coral assemblages along the Florida reef tract. Mar Ecol Prog Ser 467:89-96

> Carpenter RC (1984) Predator and population density control of homing behavior in the Caribbean echinoid Diadema antillarum. Mar Biol 82:101-108

Carpenter RC (1985) Relationships between primary production in coral reef algal communities and irradiance. Limnol Oceanogr 30:784-793

Carpenter RC (1986) Partitioning herbivory and its effects on coral reef algal communities. Ecol Monogr 56:345-364

Carpenter RC (1990) Mass mortality of Diadema antillarum. II. Effects on population densities and grazing intensity of parrotfishes and surgeonfishes. Mar Biol 104:79-86

Carpenter RC (1997) Invertebrate predators and grazers. In: Birkeland C (ed) Life and death of coral reefs. Chapman \& Hall, New York, NY, p 198-226

> Carpenter RC, Edmunds PJ (2006) Local and regional scale recovery of Diadema promotes recruitment of scleractinian corals. Ecol Lett 9:271-280

> Catano LB, Shantz AA, Burkepile DE (2014) Predation risk, competition, and territorial damselfishes as drivers of herbivore foraging on Caribbean coral reefs. Mar Ecol Prog Ser 511:193-207

Choat JH, Robbins WD, Clements KD (2004) The trophic status of herbivorous fishes on coral reefs. II. Food processing modes and trophodynamics. Mar Biol 145: $445-454$
Chollett I, Mumby PJ (2013) Reefs of last resort: locating and assessing thermal refugia in the wider Caribbean. Biol Conserv 167:179-186

> Clua E, Legendre P (2008) Shifting dominance among scarid species on reefs representing a gradient of fishing pressure. Aquat Living Resour 21:339-348

> Comeros-Raynal MT, Choat JH, Polidoro BA, Clements KD and others (2012) The likelihood of extinction of iconic and dominant herbivores and detritivores of coral reefs: the parrotfishes and surgeonfishes. PLoS ONE 7:e39825

Connell JH (1997) Disturbance and recovery of coral assemblages. Coral Reefs 16:S101-S113

> Connell JH, Hughes TP, Wallace CC (1997) A 30-year study of coral abundance, recruitment, and disturbance at several scales in space and time. Ecol Monogr 67:461-488

Cowen RK, Paris CB, Srinivasan A (2006) Scaling of connectivity in marine populations. Science 311:522-527

Debrot D, Choat JH, Posada JM, Roberstson DR (2008) High densities of the large bodied parrotfishes (Scaridae) at two Venezuelan offshore reefs: comparison among four localities in the Caribbean. Proceedings of the 60th Gulf and Caribbean Fisheries Institute, Punta Cana, Dominican Republic, p 335-338

Diaz-Pulido G, Gouezo M, Tilbrook B, Dove S, Anthony KRN (2011) High $\mathrm{CO}_{2}$ enhances the competitive strength of seaweeds over corals. Ecol Lett 14:156-162

Dill LM, Heithaus MR, Walters CJ (2003) Behaviorally mediated indirect interactions in marine communities and their conservation implications. Ecology 84:1151-1157

Donner SD, Knutson TR, Oppenheimer M (2007) Modelbased assessment of the role of human-induced climate change in the 2005 Caribbean coral bleaching event. Proc Natl Acad Sci USA 104:5483-5488

Dulvy NK, Polunin NVC, Mill AC, Graham NAJ (2004) Size structural change in lightly exploited coral reef fish communities: evidence for weak indirect effects. Can J Fish Aquat Sci 61:466-475

Eakin CM, Morgan JA, Heron SF, Smith TB and others (2010) Caribbean corals in crisis: record thermal stress, bleaching, and mortality in 2005. PLoS ONE 5:e13969

Edmunds PJ, Carpenter RC (2001) Recovery of Diadema antillarum reduces macroalgal cover and increases abundance of juvenile corals on a Caribbean reef. Proc Natl Acad Sci USA 98:5067-5071

> Edmunds PJ, Elahi R (2007) The demographics of a 15-year decline in cover of the Caribbean reef coral Montastraea annularis. Ecol Monogr 77:3-18

Edwards HJ, Elliott IA, Eakin CM, Irikawa A and others (2011) How much time can herbivore protection buy for coral reefs under realistic regimes of hurricanes and coral bleaching? Global Change Biol 17:2033-2048

Edwards CB, Friedlander AM, Green AG, Hardt MJ and others (2014) Global assessment of the status of coral reef herbivorous fishes: evidence for fishing effects. Proc R Soc Lond B Biol Sci 281:20131835

> Elmqvist T, Folke C, Nyström M, Peterson G, Bengtsson J, Walker B, Norberg J (2003) Response diversity, ecosystem change, and resilience. Front Ecol Environ 1: 488-494

Fabricius KE (2005) Effects of terrestrial runoff on the ecology of corals and coral reefs: review and synthesis. Mar Pollut Bull 50:125-146

> Falter JL, Atkinson MJ, Merrifield MA (2004) Mass-transfer limitation of nutrient uptake by a wave-dominated reef flat community. Limnol Oceanogr 49:1820-1831 
Fitzpatrick SM, Keegan WF (2007) Human impacts and adaptations in the Caribbean Islands: an historical ecology approach. Earth Environ Sci Trans R Soc Edinb 98:29-45

Fox RJ, Bellwood DR (2007) Quantifying herbivory across a coral reef depth gradient. Mar Ecol Prog Ser 339:49-59

Friedlander AM, DeMartini EE (2002) Contrasts in density, size, and biomass of reef fishes between the northwestern and the main Hawaiian islands: the effects of fishing down apex predators. Mar Ecol Prog Ser 230:253-264

Fung T, Seymour RM, Johnson CR (2011) Alternative stable states and phase shifts in coral reefs under anthropogenic stress. Ecology 92:967-982

Furman B, Heck KL (2009) Differential impacts of echinoid grazers on coral recruitment. Bull Mar Sci 85:121-132

Gardner TA, Côté IM, Gill JA, Grant A, Watkinson AR (2003) Long-term region-wide declines in Caribbean corals. Science 301:958-960

Gardner TA, Côté IM, Gill JA, Grant A, Watkinson AR (2005) Hurricanes and Caribbean coral reefs: impacts, recovery patterns, and role in long-term decline. Ecology 86:174-184

> Garrison V, Rogers C, Beets J, Friedlander A (2004) The habitats exploited and the species trapped in a Caribbean island trap fishery. Environ Biol Fishes 71:247-260

Geister J (1977) The influence of wave exposure on the ecological zonation of Caribbean coral reefs. Proc 3rd Int Coral Reef Symp 2:23-29

Gilmour JP, Smith LD, Heyward AJ, Baird AH, Pratchett MS (2013) Recovery of an isolated coral reef system following severe disturbance. Science 340:69-71

Glynn PW (1985) Corallivore population sizes and feeding effects following El Niño (1982-1983) associated coral mortality in Panama. Proc 5th Int Coral Reef Symp 4: 183-188

Glynn PW (1997) Bioerosion and coral reef growth: a dynamic balance. In: Birkeland C (ed) Life and death of coral reefs. Chapman \& Hall, New York, NY, p 68-94

Goreau T (1959) The ecology of Jamaican coral reefs. I. Species composition and zonation. Ecology 40:67-90

> Gowan JC, Tootell JS, Carpenter RC (2014) The effects of water flow and sedimentation on interactions between massive Porites and algal turf. Coral Reefs 33:651-663

Graham NAJ, Wilson SK, Jennings S, Polunin NVC, Bijoux JP, Robinson J (2006) Dynamic fragility of oceanic coral reef ecosystems. Proc Natl Acad Sci USA 103:8425-8429

Green DH, Edmunds PJ, Carpenter RC (2008) Increasing relative abundance of Porites astreoides on Caribbean reefs mediated by an overall decline in coral cover. Mar Ecol Prog Ser 359:1-10

> Guarderas AP, Hacker SD, Lubchenco J (2011) Ecological effects of marine reserves in Latin America and the Caribbean. Mar Ecol Prog Ser 429:219-225

Hallock P (1988) The role of nutrient availability in bioerosion: consequences to carbonate buildups. Palaeogeogr Palaeoclimatol Palaeoecol 63:275-291

Harrington L, Fabricius K, De'Ath G, Negri A (2004) Recognition and selection of settlement substrata determine post-settlement survival in corals. Ecology 85:3428-3437

Hawkins JP, Roberts CM (2003) Effects of fishing on sexchanging Caribbean parrotfishes. Biol Conserv 115: 213-226

> Hawkins JP, Roberts CM, Dytham C, Schelten C, Nugues MM (2006) Effects of habitat characteristics and sedimentation on performance of marine reserves in St.
Lucia. Biol Conserv 127:487-499

Hay ME (1984) Patterns of fish and urchin grazing on Caribbean coral reefs: Are previous results typical? Ecology 65:446-454

Hay ME (1985) Spatial patterns of herbivore impact and their importance in maintaining algal species richness. Proc 5th Int Coral Reef Congr 4:29-34

Hay ME (1991) Fish-seaweed interactions on coral reefs: effects of herbivorous fishes and adaptations of their prey. In: Sale PF (ed) The ecology of fishes on coral reefs. Academic Press, San Diego, CA, p 96-120

> Hay ME (1997) The ecology and evolution of seaweed-herbivore interactions on coral reefs. Coral Reefs 16:S67-S76

Hay ME, Colburn T, Downing D (1983) Spatial and temporal patterns in herbivory on a Caribbean fringing reef: the effects on plant distribution. Oecologia 58:299-308

> Hoegh-Guldberg O, Mumby PJ, Hooten AJ, Steneck RS and others (2007) Coral reefs under rapid climate change and ocean acidification. Science 318:1737-1742

> Hoey AS, Bellwood DR (2011) Suppression of herbivory by macroalgal density: a critical feedback on coral reefs? Ecol Lett 14:267-273

$>$ Hofmann GE, Barry JP, Edmunds PJ, Gates RD, Hutchins DA, Klinger T, Sewell MA (2010) The effect of ocean acidification on calcifying organisms in marine ecosystems: an organism-to-ecosystem perspective. Annu Rev Ecol Evol Syst 41:127-147

$>$ Hughes TP (1994) Catastrophes, phase shifts, and largescale degradation of a Caribbean coral reef. Science 265:1547-1551

> Hughes TP, Tanner JE (2000) Recruitment failure, life histories, and long-term decline of Caribbean corals. Ecology 81:2250-2263

Hughes TP, Rodrigues MJ, Bellwood DR, Ceccarelli D and others (2007) Phase shifts, herbivory, and the resilience of coral reefs to climate change. Curr Biol 17:360-365

Hughes TP, Graham NAJ, Jackson JBC, Mumby PJ, Steneck RS (2010) Rising to the challenge of sustaining coral reef resilience. Trends Ecol Evol 25:633-642

> Idjadi JA, Haring RN, Precht WF (2010) Recovery of the sea urchin Diadema antillarum promotes scleractinian coral growth and survivorship on shallow Jamaican reefs. Mar Ecol Prog Ser 403:91-100

Jackson JBC (1991) Adaptation and diversity of reef corals. Bioscience 41:475-482

Jackson JBC (1992) Pleistocene perspectives on coral reef community structure. Integr Comp Biol 32:719-731

> Jackson JBC (1997) Reefs since Columbus. Coral Reefs 16:S23-S32

> Jackson JBC, Kirby MX, Berger WH, Bjorndal KA and others (2001) Historical overfishing and the recent collapse of coastal ecosystems. Science 293:629-637

Jackson JBC, Donovan M, Cramer K, Lam V (eds) (2014) Status and trends of Caribbean coral reefs 1970-2012. Global Coral Reef Monitoring Network, International Union for the Conservation of Nature Global Marine and Polar Program, Washington, DC

> Jayewardene D, Donahue MJ, Birkeland C (2009) Effects of frequent fish predation on corals in Hawaii. Coral Reefs 28:499-506

> Jompa J, McCook LJ (2002) The effects of nutrients and herbivory on competition between a hard coral (Porites cylindrica) and a brown alga (Lobophora variegata). Limnol Oceanogr 47:527-534

> Jones GP, McCormick MI, Srinivasan M, Eagle JV (2004) 
Coral decline threatens fish biodiversity in marine reserves. Proc Natl Acad Sci USA 101:8251-8253

Kleypas JA, McManus JW, Meñez LAB (1999) Environmental limits to coral reef development: Where do we draw the line? Am Zool 159:146-159

Knowlton N (1992) Thresholds and multiple stable states in coral reef community dynamics. Integr Comp Biol 32: 674-682

Knowlton N, Lang J, Keller B (1990) Case study of natural population collapse: post-hurricane predation on Jamaican staghorn corals. Smithson Contrib Mar Sci 31:1-36

Koslow JA, Hanley F, Wicklund R (1988) Effects of fishing on reef fish communities at Pedro Bank and Port Royal Cays, Jamaica. Mar Ecol Prog Ser 43:201-212

Kramer PA (2003) Synthesis of coral reef health indicators for the western Atlantic: results of the AGRA program (1997-2000). Atoll Res Bull 496:1-57

- Lapointe BE, Barile PJ, Littler MM, Littler DS (2005) Macroalgal blooms on southeast Florida coral reefs: II. Crossshelf discrimination of nitrogen sources indicates widespread assimilation of sewage nitrogen. Harmful Algae 4:1106-1122

Lessios HA (1988) Mass mortality of Diadema antillarum in the Caribbean: What have we learned? Annu Rev Ecol Syst 19:371-393

- Lessios HA (2005) Diadema antillarum populations in Panama twenty years following mass mortality. Coral Reefs 24:125-127

Lewis SM (1985) Herbivory on coral reefs: algal susceptibility to herbivorous fishes. Oecologia 65:370-375

Lewis SM (1986) The role of herbivorous fishes in the organization of a Caribbean reef community. Ecol Monogr 56:183-200

Lima SL, Dill LM (1990) Behavioral decisions made under the risk of predation: a review and prospectus. Can J Zool 68:619-640

Lipp EK, Jarrella JL, Griffin DW, Lukasik J, Jacukiewicz J, Rose JB (2002) Preliminary evidence for human fecal contamination in corals of the Florida Keys, USA. Mar Pollut Bull 44:666-670

- Lirman D (2001) Competition between macroalgae and corals: effects of herbivore exclusion and increased algal biomass on coral survivorship and growth. Coral Reefs 19:392-399

Machemer EGP, Walter JF, Serafy JE, Kerstetter DW (2012) Importance of mangrove shorelines for rainbow parrotfish Scarus guacamaia: habitat suitability modeling in a subtropical bay. Aquat Biol 15:87-98

Madin EMP, Gaines SD, Madin JS, Warner RR (2010) Fishing indirectly structures macroalgal assemblages by altering herbivore behavior. Am Nat 176:785-801

Madin EMP, Madin JS, Booth DJ (2011) Landscape of fear visible from space. Sci Rep 1:14

Manfrino C, Jacoby CA, Camp E, Frazer TK (2013) A positive trajectory for corals at Little Cayman Island. PLoS ONE 8:e75432

Mantyka CS, Bellwood DR (2007) Macroalgal grazing selectivity among herbivorous coral reef fishes. Mar Ecol Prog Ser 352:177-185

Manzello DP, Kleypas JA, Budd DA, Eakin CM, Glynn PW, Langdon C (2008) Poorly cemented coral reefs of the eastern tropical Pacific: possible insights into reef development in a high- $\mathrm{CO}_{2}$ world. Proc Natl Acad Sci USA 105:10450-10455

McAfee ST, Morgan SG (1996) Resource use by five sym- patric parrotfishes in the San Blas Archipelago, Panama. Mar Biol 125:427-437

- McClanahan TR, Cinner JE (2008) A framework for adaptive gear and ecosystem-based management in the artisanal coral reef fishery of Papua New Guinea. Aquat Conserv Mar Freshw Ecosyst 18:493-507

> McClanahan TR, Bergman K, Huitric M, McField M, Elfwing T, Nyström M, Nordemar I (2000) Response of fishes to algae reduction on Glovers Reef, Belize. Mar Ecol Prog Ser 206:273-282

McClanahan T, Polunin N, Done T (2002) Ecological states and the resilience of coral reefs. Conserv Ecol 6:18

- McCook LJ (1999) Macroalgae, nutrients and phase shifts on coral reefs: scientific issues and management consequences for the Great Barrier Reef. Coral Reefs 18: 357-367

> McManus JW, Menez LAB, Kesner-Reyes KN, Vergara SG, Ablan MC (2000) Coral reef fishing and coral-algal phase shifts: implications for global reef status. ICES J Mar Sci 57:572-578

Miller MW, Hay ME (1998) Effects of fish predation and seaweed competition on the survival and growth of corals. Oecologia 113:231-238

Miller MW, Miller SL, Malone D, Sotka EE, Szmant AM (1999) Effects of nutrients versus herbivores on reef algae : a new method for manipulating nutrients on coral reefs. Limnol Oceanogr 44:1847-1861

Miller J, Muller E, Rogers C, Waara R and others (2009) Coral disease following massive bleaching in 2005 causes $60 \%$ decline in coral cover on reefs in the US Virgin Islands. Coral Reefs 28:925-937

Morrison D (1988) Comparing fish and urchin grazing in shallow and deeper coral reef algal communities. Ecology 69:1367-1382

> Mumby PJ (2006) The impact of exploiting grazers (Scaridae) on the dynamics of Caribbean coral reefs. Ecol Appl 16:747-769

Mumby PJ (2015) Stratifying herbivore fisheries by habitat to avoid ecosystem overfishing of coral reefs. Fish Fish (in press), doi:10.1111/faf.12078

Mumby PJ, Harborne AR (2010) Marine reserves enhance the recovery of corals on Caribbean reefs. PLoS ONE 5:e8657

Mumby PJ, Steneck RS (2008) Coral reef management and conservation in light of rapidly evolving ecological paradigms. Trends Ecol Evol 23:555-563

> Mumby PJ, Edwards AJ, Arias-Gonzalez JE, Lindeman K and others (2004) Mangroves enhance the biomass of coral reef fish communities in the Caribbean. Nature 427:533-536

> Mumby PJ, Hastings A, Edwards HJ (2007) Thresholds and the resilience of Caribbean coral reefs. Nature 450: 98-101

Mumby PJ, Steneck RS, Hastings A (2013) Evidence for and against the existence of alternate attractors on coral reefs. Oikos 122:481-491

Myhre S, Acevedo-Gutiérrez A (2007) Recovery of sea urchin Diadema antillarum populations is correlated to increased coral and reduced macroalgal cover. Mar Ecol Prog Ser 329:205-210

> Nagelkerken I, van der Velde G, Gorissen MW, Meijer GJ, Van't Hof T, den Hartog C (2000) Importance of mangroves, seagrass beds and the shallow coral reef as a nursery for important coral reef fishes, using a visual census technique. Estuar Coast Shelf Sci 51:31-44 
Nagelkerken I, Roberts CM, van der Velde G, Dorenbosch $M$, van Riel $M C$, Cocheret de la Morinière $E$, Nienhuis $\mathrm{PH}$ (2002) How important are mangroves and seagrass beds for coral-reef fish? The nursery hypothesis tested on an island scale. Mar Ecol Prog Ser 244:299-305

Nash KL, Graham N, Bellwood DR (2013) Fish foraging patterns, vulnerability to fishing and implications for the management of ecosystem function across scales. Ecol Appl 23:1632-1644

> Newman MJH, Paredes GA, Sala E, Jackson JBC (2006) Structure of Caribbean coral reef communities across a large gradient of fish biomass. Ecol Lett 9:1216-1227

> Norström AV, Nyström M, Lokrantz J, Folke C (2009) Alternative states on coral reefs: beyond coral-macroalgal phase shifts. Mar Ecol Prog Ser 376:295-306

Nugues MM, Roberts CM (2003) Coral mortality and interaction with algae in relation to sedimentation. Coral Reefs 22:507-516

Nugues MM, Szmant AM (2006) Coral settlement onto Halimeda opuntia: a fatal attraction to an ephemeral substrate? Coral Reefs 25:585-591

> Nyström M, Norström AV, Blenckner T, de la Torre-Castro $\mathrm{M}$ and others (2012) Confronting feedbacks of degraded marine ecosystems. Ecosystems 15:695-710

$>$ Ogden JC (1976) Some aspects of herbivore-plant relationships on Caribbean reefs and seagrass beds. Aquat Bot 2:103-116

Ogden JC (1977) Carbonate-sediment production by parrot fish and sea urchins on Caribbean reefs. Stud Geol (Tulsa) 4:281-288

$>$ Ogden JC, Brown RA, Salesky N (1973) Grazing by the echinoid Diadema antillarum Philippi: formation of halos around West Indian patch reefs. Science 182:715-717

Paddack MJ, Sponaugle S (2008) Recruitment and habitat selection of newly settled Sparisoma viride to reefs with low coral cover. Mar Ecol Prog Ser 369:205-212

Paddack MJ, Cowen RK, Sponaugle S (2006) Grazing pressure of herbivorous coral reef fishes on low coral-cover reefs. Coral Reefs 25:461-472

> Paddack MJ, Reynolds JD, Aguilar C, Appeldoorn RS and others (2009) Recent region-wide declines in Caribbean reef fish abundance. Curr Biol 19:590-595

Pandolfi JM, Jackson JBC (2006) Ecological persistence interrupted in Caribbean coral reefs. Ecol Lett 9:818-826

Pandolfi JM, Bradbury RH, Sala E, Hughes TP and others (2003) Global trajectories of the long-term decline of coral reef ecosystems. Science 301:955-958

> Pauly D, Christensen V, Guénette S, Pitcher TJ and others (2002) Towards sustainability in world fisheries. Nature 418:689-695

> Peckarsky BL, Abrams PA, Bolnick DI, Dill LM and others (2008) Revisiting the classics: considering nonconsumptive effects in textbook examples of predator-prey interactions. Ecology 89:2416-2425

> Perry CT, Murphy GN, Kench PS, Smithers SG, Edinger EN, Steneck RS, Mumby PJ (2013) Caribbean-wide decline in carbonate production threatens coral reef growth. Nat Commun 4:1402

Pittman SJ, Dorfman D, Hile SD, Jeffrey CF, Edwards MA, Caldow C (2013) Land-sea characterization of the St. Croix East End Marine Park, US Virgin Islands. Tech Memo NOS NCCOS 170. NOAA, Silver Spring, MD

> Price N (2010) Habitat selection, facilitation, and biotic settlement cues affect distribution and performance of coral recruits in French Polynesia. Oecologia 163:747-758
Randall JE (1965) Grazing effect on sea grasses by herbivorous reef fishes in the West Indies. Ecology 46:255-260

Randall JE (1967) Food habits of reef fishes of the West Indies. Stud Trop Oceanogr 5:665-847

> Rasher DB, Hay ME (2010) Chemically rich seaweeds poison corals when not controlled by herbivores. Proc Natl Acad Sci USA 107:9683-9688

River GF, Edmunds PJ (2001) Mechanisms of interaction between macroalgae and scleractinians on a coral reef in Jamaica. J Exp Mar Biol Ecol 261:159-172

Robertson DR, Gaines SD (1986) Interference competition structures habitat use in a local assemblage of coral reef surgeonfishes. Ecology 67:1372-1383

Roff G, Mumby PJ (2012) Global disparity in the resilience of coral reefs. Trends Ecol Evol 27:404-413

Rogers CS (1990) Responses of coral reefs and reef organisms to sedimentation. Mar Ecol Prog Ser 62:185-202

> Rotjan RD, Lewis SM (2005) Selective predation by parrotfishes on the reef coral Porites astreoides. Mar Ecol Prog Ser 305:193-201

Rotjan RD, Lewis SM (2008) Impact of coral predators on tropical reefs. Mar Ecol Prog Ser 367:73-91

Russ G (2003) Grazer biomass correlates more strongly with production than with biomass of algal turfs on a coral reef. Coral Reefs 22:63-67

Ruzicka RR, Colella MA, Porter JW, Morrison JM and others (2013) Temporal changes in benthic assemblages on Florida Keys reefs 11 years after the 1997/1998 El Niño. Mar Ecol Prog Ser 489:125-141

Sammarco PW (1980) Diadema and its relationship to coral spat mortality: grazing, competition, and biological disturbance. J Exp Mar Biol Ecol 45:245-272

Sammarco PW (1982) Echinoid grazing as a structuring force in coral communities: whole reef manipulations. J Exp Mar Biol Ecol 61:31-55

> Sandin SA, McNamara DE (2012) Spatial dynamics of benthic competition on coral reefs. Oecologia 168: 1079-1090

Sandin SA, Sampayo EM, Vermeij MJA (2008) Coral reef fish and benthic community structure of Bonaire and Curaçao, Netherlands Antilles. Caribb J Sci 44:137-144

- Scheffer M, van Nes EH, Holmgren M, Hughes T (2008) Pulse-driven loss of top-down control: the critical-rate hypothesis. Ecosystems 11:226-237

> Schlager W (1981) The paradox of drowned reefs and carbonate platforms. Geol Soc Am Bull 92:197-211

> Schmitz OJ (2008) Herbivory from individuals to ecosystems. Annu Rev Ecol Evol Syst 39:133-152

Schutte VGW, Selig ER, Bruno JF (2010) Regional spatiotemporal trends in Caribbean coral reef benthic communities. Mar Ecol Prog Ser 402:115-122

Selig ER, Bruno JF (2010) A global analysis of the effectiveness of marine protected areas in preventing coral loss. PLoS ONE 5:e9278

Shantz A, Burkepile D (2014) Context-dependent effects of nutrient loading on the coral-algal mutualism. Ecology 95:1995-2005

> Sheppard CRC, Harris A, Sheppard ALS (2008) Archipelago-wide coral recovery patterns since 1998 in the Chagos Archipelago, central Indian Ocean. Mar Ecol Prog Ser 362:109-117

Soares MC, Cardoso SC, Nicolet KJ, Côté IM, Bshary R (2013) Indo-Pacific parrotfish exert partner choice in interactions with cleanerfish but Caribbean parrotfish do not. Anim Behav 86:611-615 
Steneck RS (1988) Herbivory on coral reefs: a synthesis. Proc 6th Int Coral Reef Symp 1:37-49

Streelman JT, Alfaro M, Westneat MW (2002) Evolutionary history of the parrotfishes: biogeography, ecomorphology, and comparative diversity. Evolution 56:961-971

Sutherland KP, Shaban S, Joyner JL, Porter JW, Lipp EK (2011) Human pathogen shown to cause disease in the threatened eklhorn coral Acropora palmata. PLoS ONE 6:e23468

Tolimieri N (1998) Effects of substrata, resident conspecifics and damselfish on the settlement and recruitment of the stoplight parrotfish, Sparisoma viride. Environ Biol Fishes 53:393-404

Tompkins DM, Dunn AM, Smith MJ, Telfer S (2011) Wildlife diseases: from individuals to ecosystems. J Anim Ecol 80:19-38

Toth LT, van Woesik R, Murdoch TJT, Smith SR, Ogden JC, Precht WF, Aronson RB (2014) Do no-take reserves benefit Florida's corals? 14 years of change and stasis in the Florida Keys National Marine Sanctuary. Coral Reefs 33:565-577

Trapon ML, Pratchett MS, Penin L (2011) Comparative effects of different disturbances in coral reef habitats in Moorea, French Polynesia. J Mar Biol 2011:1-11

Uthicke S, Schaffelke B, Byrne M (2009) A boom-bust phylum? Ecological and evolutionary consequences of density variations in echinoderms. Ecol Monogr 79:3-24

> Van den Hoek C, Breeman A, Bak R, Van Buurt G (1978) The distribution of algae, corals and gorgonians in relation to depth, light attenuation, water movement and grazing pressure in the fringing coral reef of Curacao, Netherlands Antilles. Aquat Bot 5:1-46

van Rooij JM, Videler JJ, Bruggemann JH (1998) High biomass and production but low energy transfer efficiency of Caribbean parrotfish: implications for trophic models of coral reefs. J Fish Biol 53:154-178

Vardi T, Williams DE, Sandin SA (2012) Population dynam-

Editorial responsibility: Peter Edmunds,

Northridge, California, USA ics of threatened elkhorn coral in the northern Florida Keys, USA. Endang Species Res 19:157-169

Vega Thurber R, Burkepile DE, Correa AMS, Thurber AR and others (2012) Macroalgae decrease growth and alter microbial community structure of the reef-building coral, Porites astreoides. PLoS ONE 7:e44246

> Vega Thurber RL, Burkepile DE, Fuchs C, Shantz AA, McMinds R, Zaneveld JR (2014) Chronic nutrient enrichment increases prevalence and severity of coral disease and bleaching. Glob Change Biol 20:544-554

Vermeij MJA, van Moorselaar I, Engelhard S, Hörnlein C, Vonk SM, Visser PM (2010) The effects of nutrient enrichment and herbivore abundance on the ability of turf algae to overgrow coral in the Caribbean. PLoS ONE 5:e14312

Walker B (1992) Biodiversity and ecological redundancy. Conserv Biol 6:18-23

> West GB, Brown JH, Enquist BJ (1997) A general model for the origin of allometric scaling laws in biology. Science 276:122-126

Whelan KRT, Miller J, Sanchez O, Patterson M (2007) Impact of the 2005 coral bleaching event on Porites porites and Colpophyllia natans at Tektite Reef, US Virgin Islands. Coral Reefs 26:689-693

Williams DE, Miller MW (2012) Attributing mortality among drivers of population decline in Acropora palmata in the Florida Keys (USA). Coral Reefs 31:369-382

> Williams ID, Polunin NVC, Hendrick VJ (2001) Limits to grazing by herbivorous fishes and the impact of low coral cover on macroalgal abundance on a coral reef in Belize. Mar Ecol Prog Ser 222:187-196

> Wisshak M, Schönberg C, Form A, Freiwald A (2012) Ocean acidification accelerates reef bioerosion. PLoS ONE 7: e45124

> Wolff N, Grober-Dunsmore R (1999) Management implications of fish trap effectiveness in adjacent coral reef and gorgonian habitats. Environ Biol Fishes 55:81-90

Submitted: September 16, 2014; Accepted: December 17, 2014 Proofs received from author(s): January 13, 2015 